\title{
The Concept of Taghyir Khalqillah Through Mufassirin Perspective: An Analysis Based on Surah al-Nisa', Verse 119
}

Mohammad Naqib Hamdan, Mohd Anuar Ramli, Mohd Farhan Md Ariffin, Hussein Azeemi Abdullah Thaidi, Muhamad Firdaus Ab Rahman, Nasiibah Ramli, Nurul Syahadah Mohamad Riza

To Link this Article: http://dx.doi.org/10.6007/IJARBSS/v12-i1/12029

DOI:10.6007/IJARBSS/v12-i1/12029

Received: 07 November 2021, Revised: 10 December 2021, Accepted: 05 January 2022

Published Online: 25 January 2022

In-Text Citation: (Hamdan et al., 2022)

To Cite this Article: Hamdan, M. N., Ramli, M. A., Ariffin, M. F. M., Thaidi, H. A. A., Rahman, M. F. A., Ramli, N., \& Riza, N. S. M. (2022). The Concept of Taghyir Khalqillah Through Mufassirin Perspective: An Analysis Based on Surah al-Nisa', Verse 119. International Journal of Academic Research in Business and Social Sciences, 12(1), 1682- 1699.

\section{Copyright: (c) 2022 The Author(s)}

Published by Human Resource Management Academic Research Society (www.hrmars.com)

This article is published under the Creative Commons Attribution (CC BY 4.0) license. Anyone may reproduce, distribute, translate and create derivative works of this article (for both commercial and non0-commercial purposes), subject to full attribution to the original publication and authors. The full terms of this license may be seen at: http://creativecommons.org/licences/by/4.0/legalcode

Vol. 12, No. 1, 2022, Pg. 1682- 1699

Full Terms \& Conditions of access and use can be found at http://hrmars.com/index.php/pages/detail/publication-ethics 


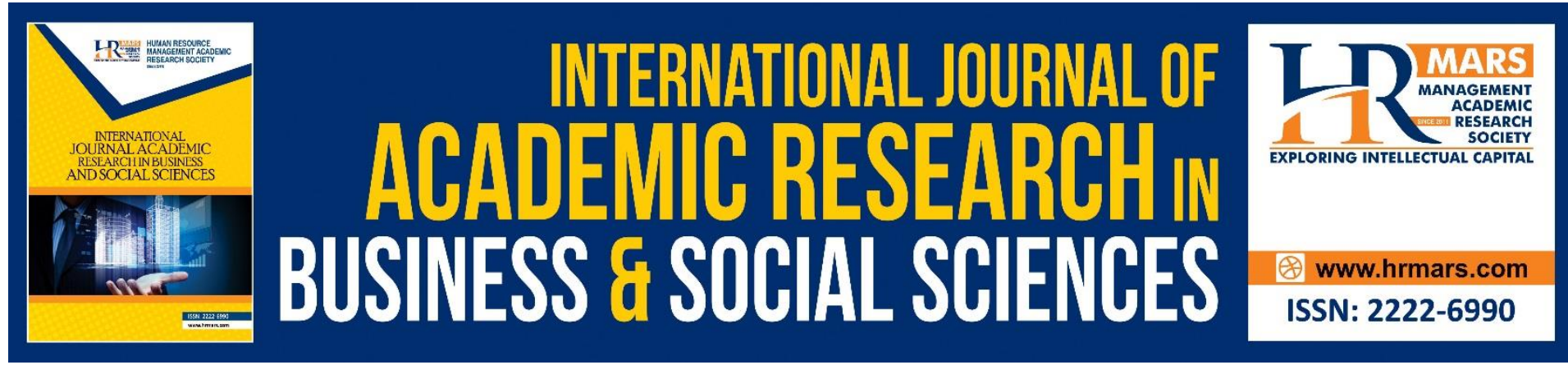

\title{
The Concept of Taghyir Khalqillah Through Mufassirin Perspective: An Analysis Based on Surah al-Nisa', Verse 119
}

Mohammad Naqib Hamdan ${ }^{1}$, Mohd Anuar Ramli², Mohd Farhan Md Ariffin ${ }^{3}$, Hussein Azeemi Abdullah Thaidi ${ }^{4}$, Muhamad Firdaus Ab Rahman ${ }^{4}$, Nasiibah Ramli ${ }^{1}$, Nurul Syahadah Mohamad Riza ${ }^{1}$

${ }^{1}$ Academy of Islamic Civilisation, Faculty of Social Sciences and Humanities, Universiti Teknologi Malaysia, 81310 Johor Bahru, Johor, Malaysia, ${ }^{2}$ Academy of Islamic Studies, University of Malaya, 50603 Kuala Lumpur, Wilayah Persekutuan Kuala Lumpur, ${ }^{3}$ Research Centre for Quran and Sunnah, Faculty of Islamic Studies, National University of Malaysia, 43600 UKM, 43600, Bangi, Selangor, ${ }^{4}$ Faculty of Syariah and Law, Islamic Science University of Malaysia, Bandar Baru Nilai, 71800 Nilai, Negeri Sembilan

Email: mohammadnaqib@utm.my,mohdanuar@um.edu.my,farhan.ariffin@ukm.edu.my, hussein@usim.edu.my,mfirdaus.rahman@usim.edu.my, nasiibah@utm.my, nurulmohamad@graduate.utm.my

\begin{abstract}
Taghyir khalqillah (alteration of Allah's creation) is one of the ways Satan misleads people. This was revealed by Allah subhanahu wa ta'ala in the Qur'an, Surah al-Nisa', verse 119 . The act of taghyir khalqillah is explicitly prohibited but the interpretation of Muslim jurist on its message vary. Therefore, this article will discuss the meaning of taghyir khalqillah in the twelve mufassirin perspectives, carefully chosen from a variety of backgrounds. The study employs qualitative research design in achieving its objectives. There are twenty-six jurists from salaf and khalaf who attempted to interpret the meaning of taghyir khalqillah in a total of fourteen interpretations. The concept of taghyir khalqillah is divided into five principles, namely (i) physical and metaphysical alteration, (ii) temporary and permanent alteration, (iii) purpose of the alteration was made, (iv) maslahah of alteration and ( $v$ ) results of the physical alteration.
\end{abstract}

Keywords: Taghyir Khalqillah, Surah Al-Nisa', Qur'anic Interpretation

\section{Introduction}

To assess the faith of His creations, the life of a Muslim is bombarded with tests from Allah subhanahu wa ta'ala. The tests come in many forms, either physical or spritual. One test experienced by mankind is through the ever-continuous deception donned by the devil. That is why, Allah subhanahu wa ta'ala has stated that the devil is the archenemy of men (Qur'an 
12:5). One of the forms of devil's deception is the alteration of Allah's creation (taghyir khalqillah) stated in Surah al-Nisa', verse 119. Allah subhanahu wa ta'ala says:

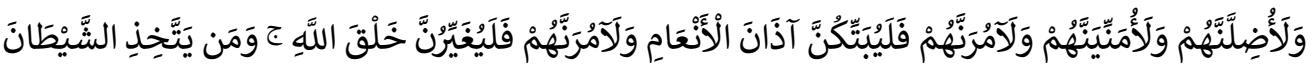

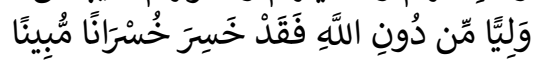

And I will mislead them, and I will arouse in them [sinful] desires, and I will command them so they will slit the ears of cattle, and I will command them so they will change the creation of Allah. And whoever takes Satan as an ally instead of Allah has certainly sustained a clear loss (Qur'an 4:119).

Based on the above verse, Allah subhanahu wa ta'ala mentions two forms of deviation that Satan desires that are to cut off the ears of farm animals and change the creation of Allah (taghyir khalqillah). Therefore, this article will discuss the scholarly debates on the concept of taghyir khalqillah (تغيير خلق الله). Taghyir khalqillah is also known as playing god in west, but there are differences between Muslim jurist's perspective and western perspective.

\section{Taghyir from the Perspective of Language}

Taghyir (تغيير) is an Arabic word derived from the verb (غَيَّرَ - يُغَيِّر). There are three other words

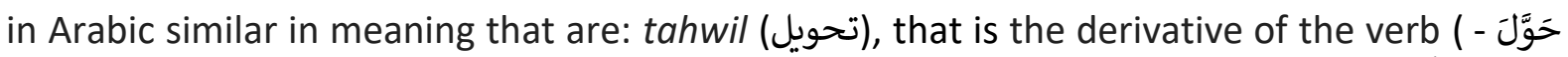

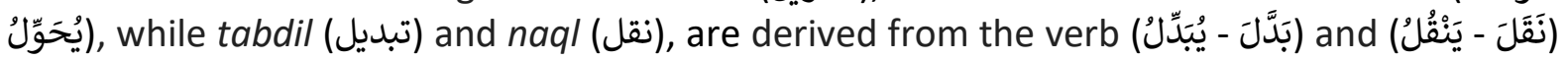
respectively. Cross-referencing the definitions of all four words, a similar meaning can be noted. Each word is used to explain the meaning between them. The following describes the definitions of the four words:

\section{T 1: Definition Of Taghyir, Tahwil, Tabdil And Naql.}

\begin{tabular}{|c|c|}
\hline Definition and Keyword & Word \\
\hline $\begin{array}{l}\text { 1. Changing the form of the original shape [Form]. } \\
\text { 2. Changing it to another object [Object] (al-Mu'jam al-'Arabiyyah, } \\
\text { 1989; 'Abd al-Mun'im, 1999; al-Asfahani, 1991). }\end{array}$ & غَيََّر - يُغَغِيٌْ - تَغْيِيْرُ \\
\hline $\begin{array}{l}\text { 1. Move to another place [Place]. } \\
\text { 2. Exchange with another object [Exchange]. } \\
\text { 3. Change the circumstances [Circumstance]. } \\
\text { 4. Planting [Plant] (al-Mu'jam al-'Arabiyyah, 1989). }\end{array}$ & حَوَّلَ - يُحَوِّلُ - تَحْوِيْلُ \\
\hline $\begin{array}{l}\text { 1. Changing the form [Form]. } \\
\text { 2. Deviate words [Words]. } \\
\text { 3. Exchange with another object [Object] (al-Mu'jam al-'Arabiyyah, } \\
\text { 1989). } \\
\text { Tabdil can be used to replace taghyir, even though taghyir is more } \\
\text { general in meaning than tabdil (al- Andalusi, 2001). }\end{array}$ & بَبَّلَ - يُبَدِّلُ - تَبَبْديْلُ \\
\hline $\begin{array}{l}\text { 1. Move to another place [Place]. } \\
\text { 2. Write one's opinion [Words]. } \\
\text { 3. Copy a book [Copy]. } \\
\text { 4. Translate [Language] (al-Mu'jam al-'Arabiyyah, 1989). }\end{array}$ & نَقَلَ - يَنْقُلُ - نَقْلُ \\
\hline $\begin{array}{l}\text { The following is the summary of the definitions of the four words: } \\
\text { Taghyir }=\{\text { Tabdil }\} \\
\text { Tabdil }=\{\text { Form, Word, Change }\} \\
\text { Tahwil }=\{\text { Place, Change, Circumstance, Plant }\} \\
\text { Naql }=\{\text { Place, Words, Copy, Translate }\}\end{array}$ & \\
\hline
\end{tabular}


Based on Table 1, there are some keywords that overlap and do not overlap. Overlapping keywords mean that they can be used to describe both words whereas non-overlapping keywords mean that they can only represent the word. Among the overlapping keywords are 'change' and 'words' that overlap between taghyir, tabdil and tahwil; and 'place' that overlaps between tahwil and naql. Non-overlapping keywords are 'form', 'circumstance', 'plant', 'copy' and 'translate'. The following shows the order of 'keywords' and 'words' in sets and subsets.

Diagram 1: Keyword and Word Arrangements

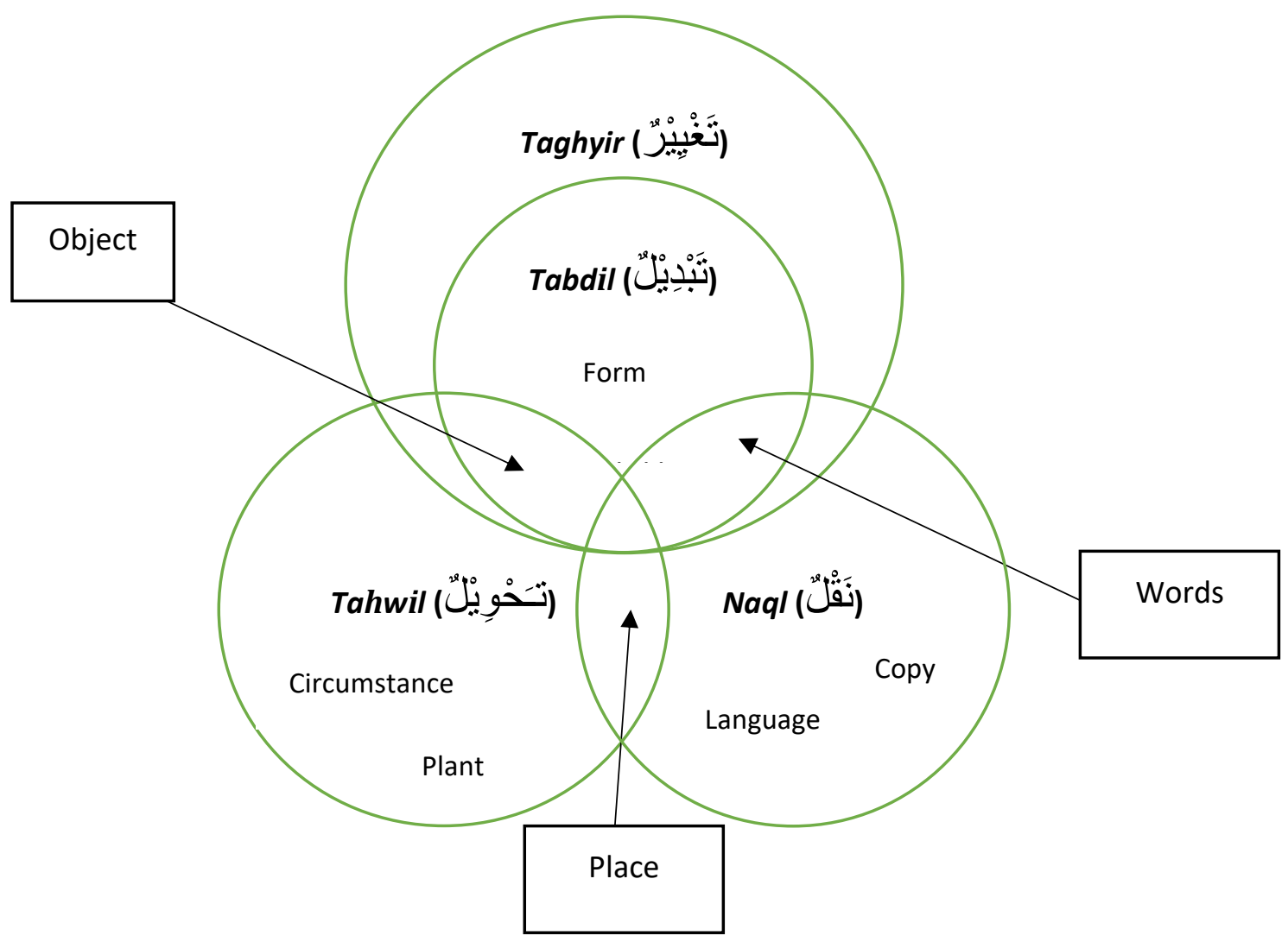

Based on Diagram 1, there is one similarity between the four aforementioned words that is the process of changing or moving from the 'origin' to 'new', regardless of change in form, place, circumstance, language or words.

\section{Taghyir in the Holy Qur'an}

An Arabic proverb says, "An example is illustrated by words." The meaning of taghyir can be illustrated by observing how it is revealed in the Qur'an. However, the word taghyir was used

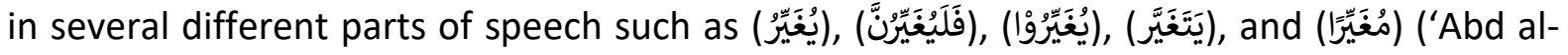

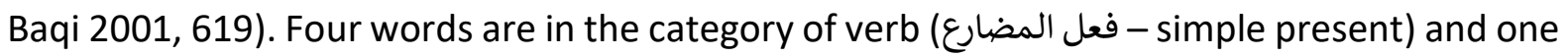
is a noun (اسم فاعل). The following illustrates complete sentences, surahs and verse numbers that contains all three words: 
Table 2: The Word Taghyir Mentioned in the Holy Qur'an

\begin{tabular}{|c|c|c|c|}
\hline No & Words & Verse & $\begin{array}{l}\text { Surah and } \\
\text { Verse } \\
\text { Number }\end{array}$ \\
\hline 1. & يُغَغِيِّ & 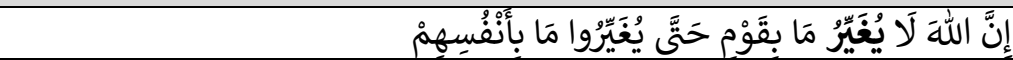 & Al-Ra'd: 11 \\
\hline 2. & فَلَيَيْغِيرُونَّ & 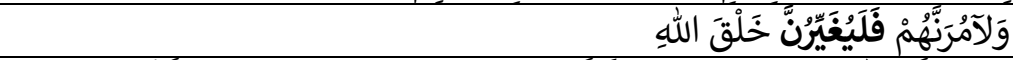 & Al-Nisa': 119 \\
\hline \multirow[t]{2}{*}{3.} & \multirow[t]{2}{*}{ يُغَغِيِّوْوْا } & 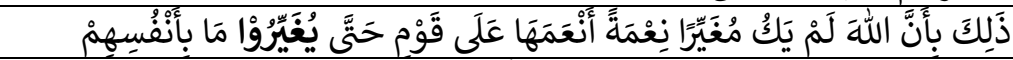 & Al-Anfal: 53 \\
\hline & & 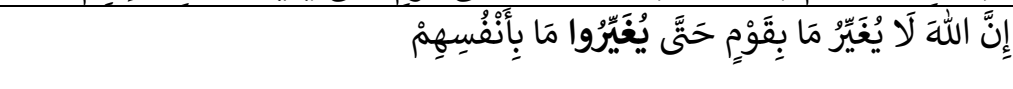 & Al-Ra'd: 11 \\
\hline 4. & مُغَيِّرًا & 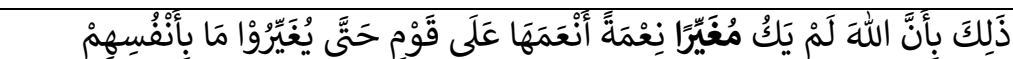 & Al-Anfal: 53 \\
\hline 5. & يَتَغَيَّر & 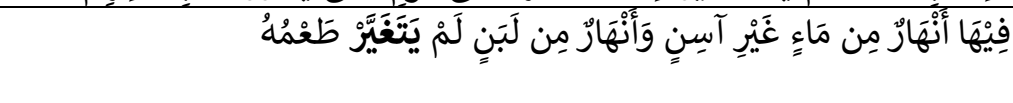 & $\begin{array}{l}\text { Muhammad: } \\
15\end{array}$ \\
\hline
\end{tabular}

Based on Table 2, taghyir divided into five types that are: self-change (تغيير ما بالأنفس) تغير)), societal change (تغيير ما بقوم), change in Allah's creation (تغيير خلق الله), change in Allah's blessings (تغيير نعم الله) and change in appetite (تغيرم).

\section{Taghyir Khalqillah According to Mufassirin}

The next discussion focuses on an in-depth interpretation of mufassirin on surah al-Nisa', verse 119. The reason being is that this verse is the basis of the concept of taghyir khalqillah. Majority of scholars will use this verse to refer to the concepts and laws of changing the creation of Allah. The discussion of the concept of taghyir khalqillah will begin by collecting data from mufassirin who have made attempts to elucidate or comment on this verse. These data will be analysed based on four angles; (i) analysing the plethora of mufassirin's background, (ii) analysis of interpretation of taghyir khalqillah and substantiation used, (iii) analysing the lists of salaf and khalaf scholars who made such attempts and (iv) analysis on the interpretation of mufassirin.

A total of 12 mufassirin were selected to observe their interpretation and analysis of the concept of taghyir khalqillah. These mufassirin come from various backgrounds of historical periods, faith, fiqhi sect and types of interpretation; included are mufassirin from the $4^{\text {th }}$ century hijriah to the $14^{\text {th }}$ century hijriah; the Ahl al-Sunnah wa al-Jama'ah (ASWJ), Shi'ites or Mu'tazilites, school of thought (madhhab) of Hanafi, Maliki, Shafi'i, Hanbali or others, and the types of interpretation of Tafsir bi al-Ma'thur, Tafsir bi al-Ra'y al-Ja'iz, Tafsir bi al-Ra'y al-Madhmum, Tafsir al-Fuqaha', Tafsir al-Shi' $i$ and Tafsir al-'Imi. All their interpretations and comments on surah al-Nisa' verse 119 were translated and transcribed. Table 3 shows the list of interpreted books used and mufassirin who wrote the book. 
Table 3: List of Books of Tafsir and the Writers

\begin{tabular}{|l|l|l|l|}
\hline No. & Book Title & Name of Mufassirin & $\begin{array}{l}\text { Died (hijri } \\
\text { calendar) }\end{array}$ \\
\hline 1. & Jami' al-Bayan & Al-Tabari (nd.) & $310 \mathrm{H}$ \\
\hline 2. & Ahkam al-Qur'an & Al-Jassas (1992) & $370 \mathrm{H}$ \\
\hline 3. & al-Kashshaf & Al-Zamakhshari (1998) & $538 \mathrm{H}$ \\
\hline 4. & Ahkam al-Qur'an & Ibn al-'Arabi (2003) & $543 \mathrm{H}$ \\
\hline 5. & al-Muharrar al-Wajiz & Ibn 'Atiyyah (2001) & $546 \mathrm{H}$ \\
\hline 6. & Mafatih al-Ghayb & Al-Razi (1981) & $606 \mathrm{H}$ \\
\hline 7. & Al-Jami' li Ahkam al-Qur'an & Al-Qurtubi (2006) & $671 \mathrm{H}$ \\
\hline 8. & Al-Bahr al-Muhit & Abu Hayyan al-Andalusi (1993) & $745 \mathrm{H}$ \\
\hline 9. & Tafsir al-Qur'an al-'Azim & Ibn Kathir (1999) & $774 \mathrm{H}$ \\
\hline 10. & Fath al-Qadir & Al-Shawkani (2007) & $1250 \mathrm{H}$ \\
\hline 11. & Tafsir al-Qur'an al-Hakim & Muhammad 'Abduh (1910) & $1323 \mathrm{H}$ \\
\hline 12. & Tafsir al-Manar & Muhammad Rashid Rida (1910) & $1354 \mathrm{H}$ \\
\hline
\end{tabular}

\section{Analysis of the Mufassirin Background Distribution}

The background distribution of mufassirin is based on the historical period (year of hijrah), faith, figh and types of interpretation of the books they have written as shown in Table 4. The arrangement of mufassirin is based on the year of demise of every mufassirin. This classification of the background of mufassirin was made by referring to the book of Siyar A'lam al-Nubala' written by al-Dhahabi (1985) and book al-Tafsir wa al-Mufassirun by Muhammad Husin al-Dhahabi and his son, Mustafa (2005).

Table 4: Mufassirin Background Distribution by Century and Faith

\begin{tabular}{|c|c|c|c|c|c|c|c|c|c|c|c|c|c|c|c|}
\hline \multirow[b]{2}{*}{ No. } & \multirow[b]{2}{*}{ Name } & \multicolumn{11}{|c|}{ Century (Hijriah) } & \multicolumn{3}{|l|}{ Faith } \\
\hline & & 4 & 5 & 6 & 7 & 8 & 9 & 10 & 11 & 12 & 13 & 14 & ASWJ & $\begin{array}{l}\text { Shiah } \\
\text { Zaidi } \\
\end{array}$ & Mu'tazilah \\
\hline 1. & Al-Tabari & $\sqrt{ }$ & & & & & & & & & & & $\sqrt{ }$ & & \\
\hline 2. & Al-Jassas & $\sqrt{ }$ & & & & & & & & & & & $\sqrt{ }$ & & \\
\hline 3. & Al-Zamakhshari & & & $\sqrt{ }$ & & & & & & & & & & & $\sqrt{ }$ \\
\hline 4. & Ibn al-'Arabi & & & $\sqrt{ }$ & & & & & & & & & $\sqrt{ }$ & & \\
\hline 5. & Ibn 'Atiyyah & & & $\sqrt{ }$ & & & & & & & & & $\sqrt{ }$ & & \\
\hline 6. & Al-Razi & & & & $\sqrt{ }$ & & & & & & & & $\sqrt{ }$ & & \\
\hline 7. & Al-Qurtubi & & & & $\sqrt{ }$ & & & & & & & & $\sqrt{ }$ & & \\
\hline 8. & $\begin{array}{l}\text { Abu Hayyan } \\
\text { al-Andalusi }\end{array}$ & & & & & $\sqrt{ }$ & & & & & & & $\sqrt{ }$ & & \\
\hline 9. & Ibn Kathir & & & & & $\sqrt{ }$ & & & & & & & $\sqrt{ }$ & & \\
\hline 10. & Al-Shawkani & & & & & & & & & & $\sqrt{ }$ & & & $\sqrt{ }$ & \\
\hline 11. & $\begin{array}{l}\text { Muhammad } \\
\text { 'Abduh }\end{array}$ & & & & & & & & & & & $\sqrt{ }$ & $\sqrt{ }$ & & \\
\hline 12. & $\begin{array}{l}\text { Muhammad } \\
\text { Rashid Rida }\end{array}$ & & & & & & & & & & & $\sqrt{ }$ & $\sqrt{ }$ & & \\
\hline
\end{tabular}

Table 4 shows the background distribution of the selected mufassirin. The mufassirin chosen from innumerable backgrounds, from the $4^{\text {th }}$ century to the $14^{\text {th }}$ century. In terms of 
faith, the majority of mufassirin held the Ahl al-Sunnah wa al-Jama'ah (ASWJ) as the core faith (83.4\%), followed by the Shia faith (8.3\%) and Mu'tazilah (8.3\%).

Table 5: Mufassirin Background Distribution by Fiqh Sect and Types of Interpretation

\begin{tabular}{|c|c|c|c|c|c|c|c|c|c|c|c|c|c|}
\hline \multirow[b]{2}{*}{ No. } & \multirow[b]{2}{*}{ Name } & \multicolumn{6}{|c|}{ Fiqh Sect } & \multicolumn{6}{|c|}{ Types of Interpretation } \\
\hline & & $\begin{array}{l}\text { T } \\
\stackrel{0}{3} \\
\stackrel{0}{\exists}\end{array}$ & $\frac{3}{0.3}$ & 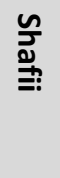 & 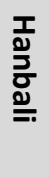 & 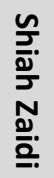 & Others & بالمأثور & تفالبير & المذارأي & الفقهاء & الشيعير & تفلمير \\
\hline 1. & Al-Tabari & & & & & & $\begin{array}{c}\sqrt{ } \\
\text { (Tabari) }\end{array}$ & $\sqrt{ }$ & & & & & \\
\hline 2. & Al-Jassas & $\sqrt{ }$ & & & & & & & & & $\sqrt{ }$ & & \\
\hline 3. & Al-Zamakhshari & $\sqrt{ }$ & & & & & & & & $\sqrt{ }$ & & & \\
\hline 4. & Ibn al-'Arabi & & $\sqrt{ }$ & & & & & & & & $\sqrt{ }$ & & \\
\hline 5. & Ibn 'Atiyyah & & $\sqrt{ }$ & & & & & $\sqrt{ }$ & & & & & \\
\hline 6. & Al-Razi & & & $\sqrt{ }$ & & & & & $\sqrt{ }$ & & & & \\
\hline 7. & Al-Qurtubi & & $\sqrt{ }$ & & & & & & & & $\sqrt{ }$ & & \\
\hline 8. & $\begin{array}{l}\text { Abu Hayyan al- } \\
\text { Andalusi }\end{array}$ & & & & & & $\begin{array}{c}\sqrt{ } \\
\text { (Zahiri) } \\
\end{array}$ & & $\sqrt{ }$ & & & & \\
\hline 9. & Ibn Kathir & & & $\sqrt{ }$ & & & & $\sqrt{ }$ & & & & & \\
\hline 10. & Al-Shawkani & & & & & $\sqrt{ }$ & & & & & & $\sqrt{ }$ & \\
\hline 11. & $\begin{array}{l}\text { Muhammad } \\
\text { 'Abduh }\end{array}$ & & & & & & & & & & & & $\sqrt{ }$ \\
\hline 12. & $\begin{array}{l}\text { Muhammad } \\
\text { Rashid Rida }\end{array}$ & & & & & & & & & & & & $\sqrt{ }$ \\
\hline
\end{tabular}

In the background distribution between madhhabs: Hanafi (16.7\%), Maliki (25\%), Shafi'i (16.7), Shi'ah Zaidi (8.3\%) and others (33.3\%) consisting of their own madhhab such as al-Tabari and al-Zahiri (Abu Hayyan al-Andalusi) while Muhammad Rashid Rida and Muhammad 'Abduh known as scholars with out madhhab. The percentage of the types of interpretation of Tafsir bi al-Ma'thur (25\%), Tafsir bi al-Ra'y al-Ja'iz (16.7\%), Tafsir bi al-Ra'y al-Madhmum (8.3 \%), Tafsir al-Fuqaha' (25\%), Tafsir al-Shi'i (8.3\%) and Tafsir al-'Ilmi (16.7\%). This diverse selection of mufassirin can at least represent the views of each category.

\section{List of Scholars of Salaf and Khalaf Who Contributed an Interpretation}

In this study, the definition of salaf and khalaf refers to the generation that lived in the first three centuries as the generation of salaf and privileged to live in the succeeding generation as the generation of khalaf. This is in line with the hadith of the Prophet sal-Allahu 'alaihi wa sallam:

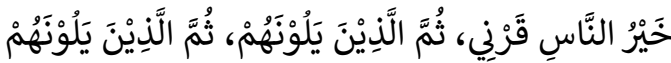

Translation: "The best of men is my age, then a century after that, then a century after that" (al-Bukhari, 2001; Muslim, 1954).

According to al-Nawawi, the first generation is the generation of the companions, the second century is tabi'in and the third century is the generation of tabi'tabi'in (al-Nawawi, 1972). 
INTERNATIONAL JOURNAL OF ACADEMIC RESEARCH IN BUSINESS AND SOCIAL SCIENCES

Vol. 12, No. 1, 2022, E-ISSN: 2222-6990 @ 2022 HRMARS

\begin{tabular}{|c|c|c|c|c|c|c|c|c|c|c|c|c|c|c|c|c|}
\hline No. & $\begin{array}{c}\text { Meaning of } \\
\text { taghyir khalqillah }\end{array}$ & 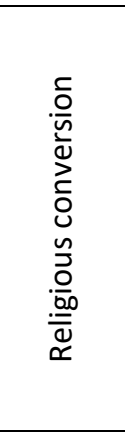 & 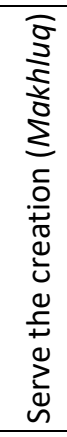 & 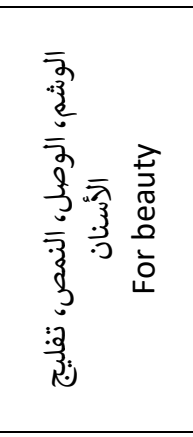 & 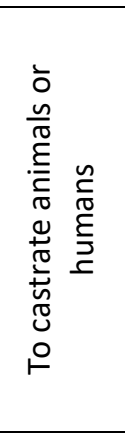 & 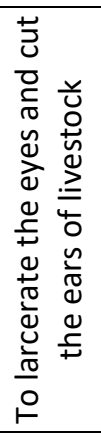 & 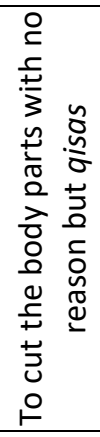 & 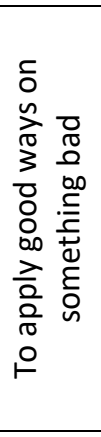 & 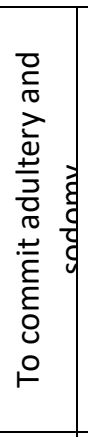 & 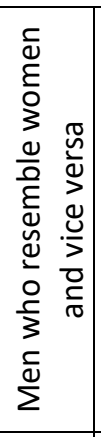 & 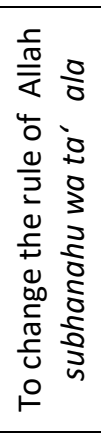 & 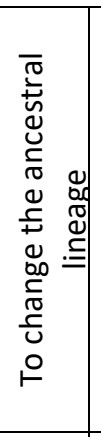 & 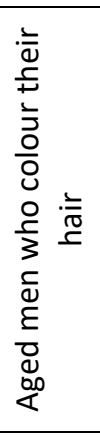 & 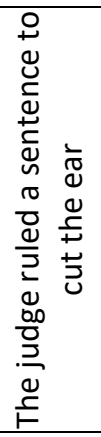 & 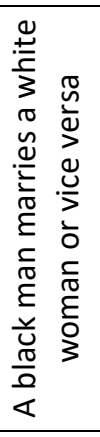 & 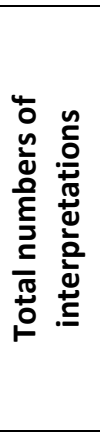 \\
\hline 1. & Ibn Mas'ud (d.32H) & & & ط ج زعط ق ح & & & & & & & & & & & & 1 \\
\hline 2. & Ibn ‘Abbas (d.68H) & ك ش عط حرح & & 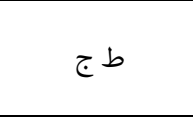 & 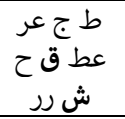 & ق & & & & & ج & & & & & 5 \\
\hline 3. & Ibn ‘Umar (d.73H) & & & & ق ك ش & & & & & & & & & & & 1 \\
\hline 4. & Abu 'Iyad (d.65-86H) & & & & s) & & & & & & & & & & & 1 \\
\hline 5. & Anas bin Malik (d.93H) & & & & ر ط ج عط رر & رز ق & & & & & & & & & & 2 \\
\hline 6. & Sa'id bin al-Musayyab (d.93H) & j) & & & s & & & & & & & & & & & 2 \\
\hline 7. & Sa'id bin Jubair (d.95H) & 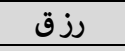 & & & & & & & & & & & & & & 1 \\
\hline 8. & Ibrahim al-Nakha'i (d.96H) & 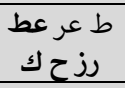 & & & & & & & & & ج & & & & & 2 \\
\hline 9. & Kharijah bin Zayd (d.100H) & b & & & & & & & & رز & & & & & & 2 \\
\hline 10. & Abu Salih (d.101H) & & & & 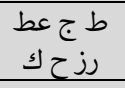 & 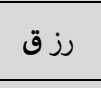 & & & & & & & & & & 2 \\
\hline 11. & $\begin{array}{l}\text { Al-Dahhak bin Muzahim } \\
\text { (d.102H) }\end{array}$ & ط رزق & & & & & & & & & ج & & & & & 2 \\
\hline 12. & Mujahid (d.103H) & 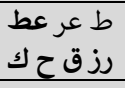 & & & $\tau$ & & & & & & ج & & & & & 3 \\
\hline 13. & 'Ikrimah (d.105H) & ط ك & & & 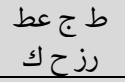 & 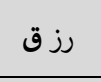 & & & & & & & & & & 3 \\
\hline 14. & Tawus (d.106H) & & & & & & & & & & & & & & عرق & 1 \\
\hline 15. & Qatadah (d.110H) & 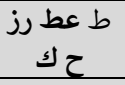 & & & ك & & & & & & & & & & & 2 \\
\hline 16. & Hasan al-Basri (d.110H) & 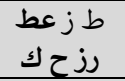 & & ط ج عر رزق ح & b & & & & & & ج & & & & & 4 \\
\hline 17. & Shahr bin Hawshab (d.111H) & & & & ج رز & رز & & & & & & & & & & 2 \\
\hline
\end{tabular}


INTERNATIONAL JOURNAL OF ACADEMIC RESEARCH IN BUSINESS AND SOCIAL SCIENCES

Vol. 12, No. 1, 2022, E-ISSN: 2222-6990 @ 2022 HRMARS

\begin{tabular}{|c|c|c|c|c|c|c|c|c|c|c|c|c|c|c|c|c|}
\hline 18. & $\begin{array}{l}\text { Al-Qasim bin Abu Bazzah } \\
\text { (d.114H) }\end{array}$ & $b$ & & & & & & & & & & & & & & 1 \\
\hline 19. & Al-Hakam (d.115H) & s) & & & & & & & & & & & & & & 1 \\
\hline 20. & Al-Sudda (d.127H) & ط رز ك & & & & & & & & & ج & & & & & 2 \\
\hline 21. & 'Ata' al-Khurasani (d.135H) & ك & & & & & & & & & & & & & & 1 \\
\hline 22. & Al-Rabi“ bin Anas (d.140H) & & & & $b$ & & & & & & & & & & & 1 \\
\hline 23. & Sufyan al-Thawri (d.161H) & & & & s) & & & & & & & & & & & 1 \\
\hline 24. & Al-Zujjaj (d.311H) & & رزق & & & & & & & & رز & & & & & 2 \\
\hline 25. & $\begin{array}{l}\text { Abu 'Umar bin 'Abd al-Barr } \\
\text { (d. } 463 \mathrm{H})\end{array}$ & & & & & & 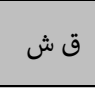 & & & & & & & & & 1 \\
\hline 26. & Al-Zamakhshari (d.538H) & & & & & 2 & & & & & & & & & & 1 \\
\hline & $\begin{array}{l}\text { The author simply mentions } \\
\text { the views without referring to } \\
\text { anyone }\end{array}$ & عب عب & عط ش & נر & j & j & & ح & $\tau$ & 乙j & $\tau$ & $\tau$ & ح & ح & & \\
\hline & $\begin{array}{l}\text { Total numbers of } \\
\text { interpretators }\end{array}$ & $14(1)$ & $1(1)$ & $3(1)$ & $13(1)$ & $6(1)$ & 1 & (1) & (1) & (1) & $7(1)$ & (1) & (1) & (1) & 1 & \\
\hline
\end{tabular}

Table 6: Analysis of Companions, Tabi'in, Tabi' Tabi'in and Khalaf Clerics

\begin{tabular}{|l|l|}
\hline & $\begin{array}{l}\text { Generation of Prophet's } \\
\text { companions }\end{array}$ \\
\hline & $\begin{array}{l}\text { Generation of Tabi'in } \\
\text { clerics }\end{array}$ \\
\hline $\mathbf{( 1 )}$ & $\begin{array}{l}\text { Numbers of abstained } \\
\text { interpretations }\end{array}$ \\
\hline
\end{tabular}

\begin{tabular}{|c|c|c|c|}
\hline $\begin{array}{l}\text { Name of } \\
\text { Clerics }\end{array}$ & Code & $\begin{array}{l}\text { Name of } \\
\text { Clerics }\end{array}$ & Code \\
\hline al-Tabari & $b$ & al-Jassas & ج \\
\hline $\begin{array}{l}\text { al- } \\
\text { Zamakhshari }\end{array}$ & j & Ibn al-'Arabi & عر \\
\hline Ibn 'Atiyyah & عط & al-Razi & رj \\
\hline al-Qurtubi & ق & Abu Hayyan & $\tau$ \\
\hline Ibn Kathir & s & al-Shawkani & ش \\
\hline $\begin{array}{l}\text { Muhammad } \\
\text { 'Abduh }\end{array}$ & عب & Rashid Rida & נر \\
\hline
\end{tabular}

Note: Bolded word codes signify that the interpretation is based on substantiation. 
Table 6 shows the list of the meaning of taghyir khalqillah and clerics of salaf and khalaf who attempted to interpret the meaning. Every argument taken from Qur'anic verses or hadiths to support the proposition will be blackened (bold) to distinguish with the argument given without substantiation. In general, there are 14 meanings or interpretations about taghyir khalqillah but only 5 of these interpretations are based on the Qur'anic prophecy or the Prophet's hadiths. Meanwhile, the remaining 9 interpretations were mentioned without any proposition. The number of clerics who gave interpretation is 26 clerics.

Based on Table 6, the majority of the clerics ie Ibn 'Abbas, Sa'id bin al-Musayyab, Sa'id bin Jubair, Ibrahim al-Nakha'i, Kharijah bin Zayd, al-Dahhak bin Muzahim, Mujahid, 'Ikrimah, Qatadah, Hasan bin al-Basri, al-Qasim bin Abu Bazzah, al-Hakam, al-Sudda and 'Ata' alKhurasani interpreted taghyir khalqillah as 'to convert the religion of Allah subhanahu wa ta'ala. This is followed by the meaning of 'castrating farm animals' interpreted by Ibn 'Abbas, Ibn 'Umar, Abu 'Iyad, Anas bin Malik, Sa'id bin al-Musayyab, Abu Salih, Mujahid, 'Ikrimah, Qatadah, Hasan al-Basri, Shahr bin Hawshab, al-Rabbi' bin Anas and Sufyan al-Thawri.

The meaning of 'changing the law of Allah subhanahu wa ta'ala was also interpreted by 7 clerics namely Ibn 'Abbas, Ibrahim al-Nakha'i, al-Dahhak bin Muzahim, Mujahid, Hasan al-Basri, al-Sudda and al-Zujjaj. Consequently, the six figures of Ibn 'Abbas, Anas bin Malik, Abu Salih, 'Ikrimah, Shahr bin Hawshab, and al-Zamakhshari interpreted the meaning of taghyir khalqillah was 'to lacerate the eyes and cut the ears of livestock.' Finally, the meaning of 'al-washr, al-wasl, al-nams and taflij al-asnan' were interpreted by Ibn Mas'ud, Ibn 'Abbas and Hasan al-Basri respectively.

The four meanings of taghyir khalqillah interpretated by one scholar for each interpretation were: 'Worshiping creations (makhluq)' interpreted by al-Zujjaj, the meaning of 'To cut the body parts with no reason but qisas' interpreted by Ibn 'Abd al-Barr, the meaning of 'men who resemble women and vice versa' interpreted by Kharijah bin Zayd and the meaning of 'A black man marries a white woman or vice versa' interpreted by Tawus. The remaining five meanings of taghyir khalqillah were denoted by mufassirin, but were not referred to any of the clerics. These five interpretations are 'to apply good ways on something bad', 'to commit adultery and sodomy', 'to change the ancestral lineage', 'aged men who colour their hair' and 'the judge ruled a sentence to cut the ear.'

Ibn 'Abbas is the cleric who interpreted the meaning of taghyir khalqillah the most with five meanings, namely 'to change the religion of Allah subhanahu wa ta'ala', 'al-washr, al-wasl, al-nams and taflij al-asnan', 'to castrate livestock or humans', 'to lacerate the human eye and cutting the ears of livestock' and 'changing the law of Allah subhanahu wa ta'ala'. This is followed by Hasan al-Basri who provided four interpretations whereas Mujahid and 'Ikrimah offered three. The interpretation given by the three tabi'in figures is parallel to the interpretation given by Ibn 'Abbas, as the three interpretations encapsulate all five interpretations as a whole. This may be the case because Mujahid, 'Ikrimah and Hasan alBasri are students of Ibn 'Abbas (al-Dhahabi, 1985).

Apart from Ibn 'Abbas, there are three other figures from the companions of the Prophet Muhammad salla-Allahu 'alaihi wa sallam who interpreted the meaning of the taghyir khalqillah. They are Ibn Mas'ud, Ibn 'Umar and Anas bin Malik. Interestingly, the three companions are from the generation of sighar al-sahabah (صِغَارُ الصَّحَابَّ) , they were young companions when the Prophet Muhammad salla-Allahu 'alaihi wa sallam was still alive. Every interpretation they give was based on the proposition of either the Qur'an or the Prophet's hadith. 
A total of 19 tabi'in figures who interpreted the meaning of taghyir khalqillah. They are Abu 'Iyad, Sa'id bin al-Musayyab, Sa'id bin al-Jubair, Ibrahim al-Nakha'i, Kharijah bin Zayd, Abu Salih, al-Dahhak bin Muzahim, Mujahid, 'Ikrimah, Tawus, Qatadah, Hasan al-Basri, Shahr bin Hawshab, al-Qasim bin Abu Bazzah, al-Hakam, al-Sudda, 'Ata' al-Khurasani, al-Rabbi' bin Anas and Sufyan al-Thawri. The majority of them rely on other proponents as support except for only a few. This is because, there is a high possibility that the interpretation made without any substantiation was the ijtihad of mufassirin in interpretating the verse, as it is talking about taghyir khalqillah in a general sense.

To prove the aforementioned point, Tawus made an interpretation of taghyir khalqillah by saying that black men are prohibited to marry white women or white men are not allowed to marry black women. His views garnered criticism by (Ibn al-'Arabi, 2003; alQurtubi, 2006). According to them, the Prophet Muhammad salla-Allahu 'alaihi wa sallam arranged Zaid bin al-Harithah radiya-Allahu 'anhu to marry the black Barakah binti Tha'labah al-Habashiyyah radiya-Allahu 'anha, the black Usamah bin Zayd radiya-Allahu 'anhu to marry the white Fatimah binti Qays radiya-Allahu 'anha and the famous black Bilal bin Rabah radiyaAllahu 'anhu to marry Halah binti 'Auf al-Zuhriyyah al-Qurashiyyah radiya-Allahu 'anha, the younger sister of 'Abd al-Rahman bin 'Auf radiya-Allahu 'anhu who was white.

In fact, al-Qurtubi took his critique a step further by saying that Tawus failed to find this hadith throughout his life. This is because he was the only tabi'in who gave such an ijtihad. Kharijah bin Zayd was also the only figure who interpreted the meaning of taghyir khalqillah as 'a man resembling a woman (التَّخَنُُشُ ) or a woman resembling a man (السِّحَاقُ)'. He also did not substantiate his views on any propositions.

There are two other interpretations of khalaf uncorroborated by any propositions, ie 'worshiping creations' interpreted by al-Zujjaj and 'cutting body parts without any reason except qisas' interpreted by Ibn 'Abd al-Barr. Furthermore, the remaining five interpretations were asserted by Abu Hayyan al-Andalusi. The interpretations, not only were unsupported by any propositions, but also was not validated by any other scholars. This interpretation was described in a weak manner, through a method known as sighah tamrid (صيغة التمريض). This is a result of his methodology which combines the views of salaf and khalaf scholars. Therefore, al-Dhahabi (1985) placed it his book in Tafsir bi al-Ra'y al-Ja'iz.

Furthermore, each of the arguments used in support of their interpretation will be collected and examined, either from Qur'anic verses or the Prophet's hadith. All these arguments will be scrutinised and combined if there is an equation with meaning even though the diction used is dissimilar, especially the proposition of the hadith of the Prophet sal-Allahu 'alaihi wa sallam. The collected hadiths will go through the process of takhrij (extracted and authenticated) to facilitate the study and refer to the explanation of muhaddithin (narrator of hadith) regarding the hadith. This is because, every muhaddith has diverse explanations on different sources of hadith.

\section{Analysis of Supporting Substantiations Used by Mufassirin}

The findings from Table 6 show that there are only 5 interpretations that are corroborated to other propositions as support ie; (i) converting religion, (ii) tattoos (al-washm), connecting hair (al-wasl), thinning eyebrows (al-nams), spacing teeth (al-washr or taflij al-asnan) or any alteration with beauty purposes, (iii) castrating animals or humans, (iv) lacerate camel's eyes and cut the ears of livestock and ( $\mathrm{v}$ ) altering the law of Allah subhanahu wa ta'ala. The propositions used based on the mufassirin was compiled. Hadith sources were also extracted and authenticated to assess the level authenticity of the hadith used. The details can be found 
in Table 6. Based on Table 6, there are only two verses from the Qur'an and nine hadiths used as validation and support even though the text of the hadiths used is different.

Table 7 shows the arguments are categorised by the type of taghyir, namely Taghyir Ma'nawi (Metaphysical Change) or Taghyir Hissi (Physical Change). Evidences from number one to number four are categorised as Taghyir Ma'nawi while the numbers five to seven are categorised as Taghyir Hissi. The argument of Taghyir Ma'nawi is clear that it is to change the religion or the law of Allah subhanahu wa ta'ala. So any act that can cause humanity to change the religion or the law of Allah subhanahu wa ta'ala is forbidden. However, the discussion on Taghyir Hissi still requires an in-depth deliberation because it involves the issue of figh which is still broad and can vary based on situations. To prove the point, although Allah the Almighty forbade people from lacerating and cutting the animal's ears, some scholars allow animals to be marked with hot iron or poked with holes for a particular purpose (al-Duwaish 2003). Similarly with castrating animals, some scholars have allowed it for the purpose of fattening animals and improving the quality of meat (Ibn al-'Arabi, 2007).

Table 7: Summary of the Proposition Used and its Source

\begin{tabular}{|c|c|c|c|c|c|}
\hline No. & Mufassirin & $\begin{array}{l}\text { Meaning } \\
\text { of Taghyir } \\
\text { Khalqillah }\end{array}$ & Proposition & Source & $\begin{array}{l}\text { Type } \\
\text { Taghyir }\end{array}$ \\
\hline 1. & $\begin{array}{l}\text { Al-Tabari, al- } \\
\text { Jassas, Ibn } \\
\text { 'Atiyyah, Abu } \\
\text { Hayyan al- } \\
\text { Andalusi, Ibn } \\
\text { Kathir, Rashid } \\
\text { Rida } \\
\end{array}$ & \multirow{2}{*}{$\begin{array}{l}\text { Changing } \\
\text { the } \\
\text { religion of } \\
\text { Allah } \\
\text { subhanahu } \\
\text { wa ta'ala }\end{array}$} & 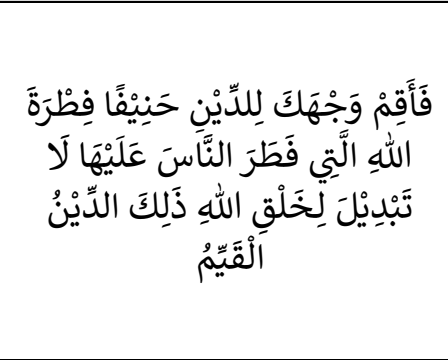 & Surah al-Rum: 30 & \multirow{2}{*}{$\begin{array}{l}\text { Taghyir } \\
\text { Ma'nawi } \\
\text { (Metaphysical } \\
\text { Change) }\end{array}$} \\
\hline 2. & $\begin{array}{l}\text { Al-Razi, Ibn } \\
\text { Kathir }\end{array}$ & & 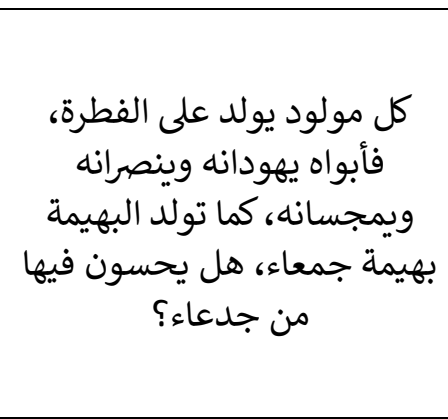 & $\begin{array}{c}\text { Al-Bukhari } \\
\text { (2001); Muslim } \\
\text { (1954); al- } \\
\text { Tirmidhi (1975); } \\
\text { Abu Dawud (nd.); } \\
\text { Ahmad (2001); } \\
\text { Ibn Hibban } \\
\text { (1993). }\end{array}$ & \\
\hline 3. & $\begin{array}{l}\text { Abu Hayyan al- } \\
\text { Andalusi }\end{array}$ & \multirow{3}{*}{$\begin{array}{l}\text { Altering } \\
\text { the law of } \\
\text { Allah } \\
\text { subhanahu } \\
\text { wa ta'ala }\end{array}$} & 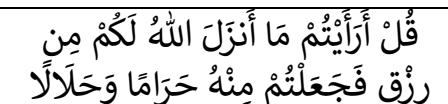 & Surah Yunus: 59 & \multirow{3}{*}{$\begin{array}{l}\text { Taghyir } \\
\text { Ma'nawi } \\
\text { (Metaphysical } \\
\text { Change) }\end{array}$} \\
\hline \multirow[t]{2}{*}{4.} & Ibn Kathir & & 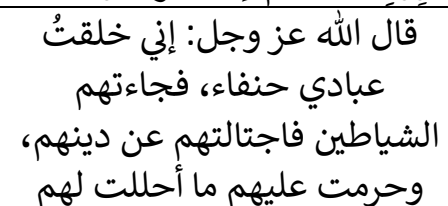 & & \\
\hline & al-Qurtubi & & 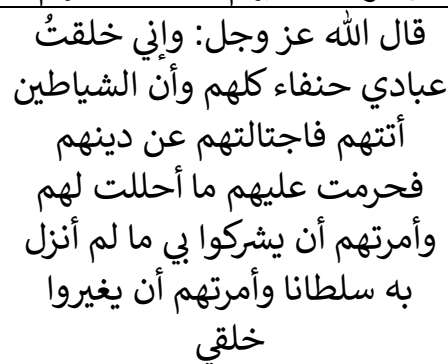 & $\begin{array}{l}\text { Muslim (1954); } \\
\text { Ahmad (2001); } \\
\text { al-Nasa'i (2001) }\end{array}$ & \\
\hline
\end{tabular}




\begin{tabular}{|c|c|c|c|c|c|}
\hline 5. & Al-Qurtubi & $\begin{array}{l}\text { Lacerate } \\
\text { the eyes of } \\
\text { a camel } \\
\text { and } \\
\text { cutting the } \\
\text { ears of } \\
\text { farm } \\
\text { animals }\end{array}$ & 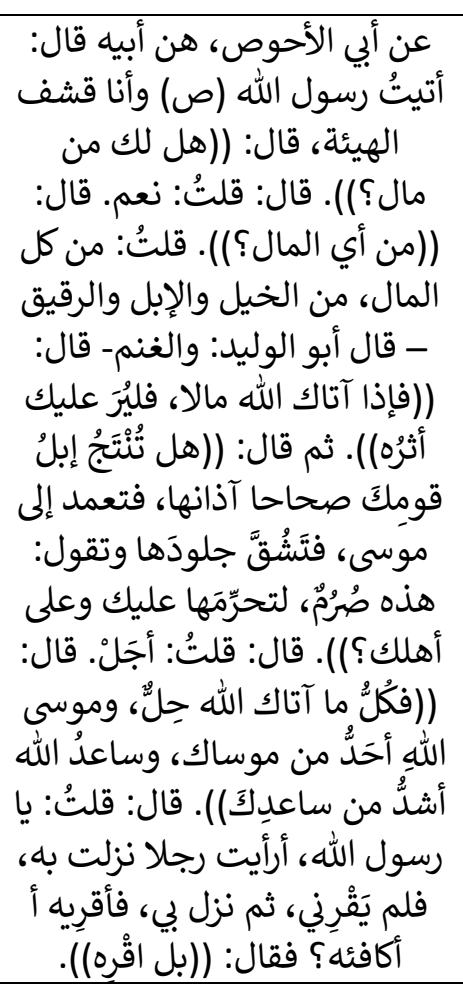 & $\begin{array}{l}\text { Ahmad (2001); } \\
\text { Abu Dawud (nd.) } \\
\text { and al-Tirmidhi } \\
\text { (1975) }\end{array}$ & \multirow[t]{4}{*}{$\begin{array}{l}\text { Taghyir Hissi } \\
\text { (Physical } \\
\text { Change) }\end{array}$} \\
\hline \multirow[t]{3}{*}{6.} & Al-Shawkani & \multirow{3}{*}{$\begin{array}{l}\text { Castrate } \\
\text { animals } \\
\text { and } \\
\text { humans }\end{array}$} & عن عن ابن عمر: نهى رسول الله البهائم والخيل. & \multirow{2}{*}{ Al-Baihaqi (2003) } & \\
\hline & al-Qurtubi & & عن ابن عمر: لا تخصوا ما ينمي & & \\
\hline & Al-Shawkani & & عن ابن عباس: نهى رسول الروح وإخصاء الله & Al-Baihaqi (2003) & \\
\hline \multirow[t]{2}{*}{7.} & $\begin{array}{lr}\text { Ibn al-'Arabi, } \\
\text { Ibn 'Atiyyah, al- } \\
\text { Razi, } \\
\text { Qurtubi, al- } \\
\text { Hayyan } \\
\begin{array}{lr}\text { Andalusi, } & \text { al- } \\
\text { Kathir, } & \text { Rashid } \\
\text { Rida }\end{array} \\
\end{array}$ & \multirow[t]{2}{*}{ الألمصل، الوشم، تفليج } & لعن الله الواصلة والمستوصلة & \multirow{2}{*}{$\begin{array}{c}\text { Al-Bukhari } \\
\text { (2001); Muslim } \\
\text { (1954); al- } \\
\text { Tirmidhi (1975); } \\
\text { al-Nasa'i (2001); } \\
\text { Abu Dawud (nd.); } \\
\text { Malik (2004); } \\
\text { Ahmad (2001) }\end{array}$} & \multirow{2}{*}{$\begin{array}{l}\text { Taghyir Hissi } \\
\text { (Physical } \\
\text { Change) }\end{array}$} \\
\hline & $\begin{array}{l}\text { al-Tabari, al- } \\
\text { Zamakhshari, } \\
\text { Ibn al-'Arabi, } \\
\text { Ibn 'Atiyyah, al- } \\
\text { Qurtubi, Abu } \\
\text { Hayyan al- } \\
\text { Andalusi, Ibn } \\
\text { Kathir, Rashid } \\
\text { Rida }\end{array}$ & & 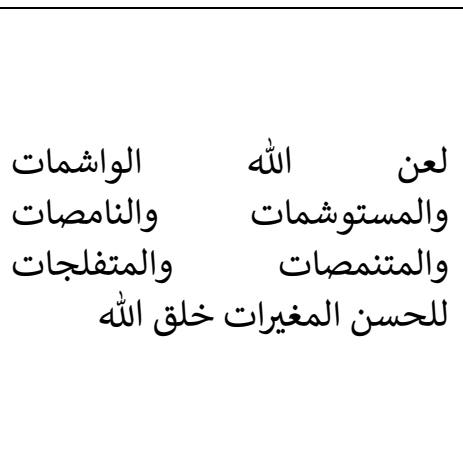 & & \\
\hline
\end{tabular}




\section{Analysis of Mufassirin's Interpretation of Taghyir Khalqillah}

Based on the content analysis of 12 commentary books, there are several pivotal points that can be used to form the basic concept of taghyir khalqillah. Five foundations have been developed to form the concept of taghyir khalqillah as listed below:
(i) Categorisation of Taghyir khalqillah,
(iv) Effects of Taghyir khalqillah,
(ii) Form of Taghyir khalqillah,
(v) Physical Results of Taghyir
(iii) Purpose of Taghyir khalqillah, khalqillah.

Table 8: Collection of Basic Concept of Taghyir Khalqillah

\begin{tabular}{|c|c|c|c|}
\hline No. & Basic Concept & Scholar & Translation of Text \\
\hline \multirow[t]{2}{*}{1.} & \multirow{2}{*}{$\begin{array}{l}\text { Categorising } \\
\text { taghyir khalqillah } \\
\text { to physical } \\
\text { change (taghyir } \\
\text { hissi) and } \\
\text { metaphysical } \\
\text { change (taghyir } \\
\text { ma'nawi) }\end{array}$} & $\begin{array}{l}\text { Muhamm } \\
\text { ad 'Abduh } \\
\text { (1910) }\end{array}$ & $\begin{array}{l}\text { A small fraction of mufassirin believes the meaning } \\
\text { of taghyir is to change religion. Other mufassirin } \\
\text { opined that it means al-Taghyir al-Hissi, al-Taghyir } \\
\text { al-Ma'nawi and a combination of both. }\end{array}$ \\
\hline & & $\begin{array}{l}\text { Rashid } \\
\text { Rida } \\
\text { (1910) }\end{array}$ & $\begin{array}{l}\text { Changing the creation of Allah subhanahu wa ta'ala } \\
\text { is divided into: } \\
\text { (i) Metaphysical change (al-taghyir al-ma'nawi), } \\
\text { for example: } \\
\text { a. Changing the religion of Allah subhanahu } \\
\text { wa ta'ala as narrated by Ibn 'Abbas } \\
\text { radiya-Allahu 'anhu based on the verse } \\
\text { "Allah's fitrah on mankid". } \\
\text { (ii) Physical change (al-taghyir al-hissi), for } \\
\text { example: } \\
\text { a. Infertile as what has been interpretated } \\
\text { by lbn 'Abbas, Anas bin Malik and others } \\
\text { radiya-Allahu 'anhum. } \\
\text { Tattooing, spacing of teeth and any change with } \\
\text { beauty purposes based on the hadith of the } \\
\text { Prophet sal-Allahu 'alaihi wa sallam: "Allah the } \\
\text { Almighty curses the tattooist and the person who } \\
\text { requested a tattoo". }\end{array}$ \\
\hline 2. & $\begin{array}{l}\text { Categorising } \\
\text { taghyir khalqillah } \\
\text { to 'Temporary } \\
\text { change' and } \\
\text { 'Permanent } \\
\text { change' }\end{array}$ & $\begin{array}{l}\text { Al-Qurtubi } \\
(2006)\end{array}$ & $\begin{array}{l}\text { According to them again, this forbiddance is on } \\
\text { permanent change, then only it is categorised as } \\
\text { taghyir khalqillah. For temporary changes such as } \\
\text { women's jewelry and eyelashes, the scholars allow } \\
\text { it for women. }\end{array}$ \\
\hline 3. & $\begin{array}{lr}\text { Observe } & \text { the } \\
\text { purpose } & \text { of } \\
\text { taghyir khalqillah }\end{array}$ & $\begin{array}{l}\text { Al-Razi } \\
(1981)\end{array}$ & $\begin{array}{l}\text { Al-Hasan said: The meaning of taghyir is to connect } \\
\text { the hair and draw a tattoo based on the hadith: } \\
\text { "Allah subhanahu wa ta'ala curses the woman who } \\
\text { connected her hair and draw a tattoo". This is } \\
\text { because they do that for adultery. }\end{array}$ \\
\hline 4. & $\begin{array}{l}\text { Observe the } \\
\text { result } \quad \text { or } \\
\text { maslahah taghyir }\end{array}$ & $\begin{array}{l}\text { Ibn } \\
\text { 'Atiyyah } \\
\text { (2001) }\end{array}$ & $\begin{array}{l}\text { According to them, castrating farm animals is } \\
\text { prohibited, but some parties allow castration of }\end{array}$ \\
\hline
\end{tabular}




\begin{tabular}{|c|c|c|c|}
\hline & $\begin{array}{l}\text { khalqillah, either } \\
\text { it gives benefits } \\
\text { or harm }\end{array}$ & & $\begin{array}{l}\text { livestock if it brings benefits, whether it is beneficial } \\
\text { to increase fat or meats. } \\
\text { The interpretation of this paragraph is that any } \\
\text { harmful alterations are prohibited and any useful } \\
\text { alterations are allowed. }\end{array}$ \\
\hline \multirow[t]{2}{*}{5.} & \multirow{2}{*}{$\begin{array}{lr}\text { Observe } & \text { the } \\
\text { physical result } \\
\text { from } & \text { taghyir } \\
\text { khalqillah } & \end{array}$} & $\begin{array}{l}\text { Ibn al- } \\
\text { ‘Arabi } \\
\text { (2007) }\end{array}$ & $\begin{array}{l}\text { All these acts hurt the animal and it is forbidden, } \\
\text { allowing evil and acts without any justification and } \\
\text { validation. }\end{array}$ \\
\hline & & $\begin{array}{l}\text { Rashid } \\
\text { Rida } \\
\text { (1910) }\end{array}$ & $\begin{array}{l}\text { Therefore, the prohibited change is the alteration } \\
\text { of the original form (al-taghyir al-suri) to an uglier } \\
\text { form. For example, circumcision, colouring of } \\
\text { fingernails and nail clipping are considered as } \\
\text { sunnah. }\end{array}$ \\
\hline
\end{tabular}

Table 8 shows the details of the basic concept of taghyir khalqillah. The first principle looks at the perspective of the division of taghyir khalqillah to taghyir hissi and taghyir ma'nawi. However, Ibn 'Atiyyah distinguishes both taghyir and tabdil. This can be seen in his statement: "Tabdil in the verse is used at the place of taghyir, although the concept of taghyir is more common than tabdi". Ibn 'Atiyyah's division only looks at language differences because there is no significant variance between these two words. In fact, if referred to the language discussion between the two words, both words signify a similar meaning and can be used to describe one another. Thus, we chose the first basis as distribution of taghyir khalqillah compared to the division of Ibn 'Atiyyah. On this basis, the fourteen meanings of the taghyir khalqillah can be categorised under this principle.

The second to fifth concept see taghyir in some bases. The second to fifth basis are the substitute to taghyir hissi because taghyir ma'nawi is not suitable to be divided into these two divisions. Finally, the concept of taghyir khalqillah according to the view of mufassirin based on these five bases is compiled in diagram 2. 


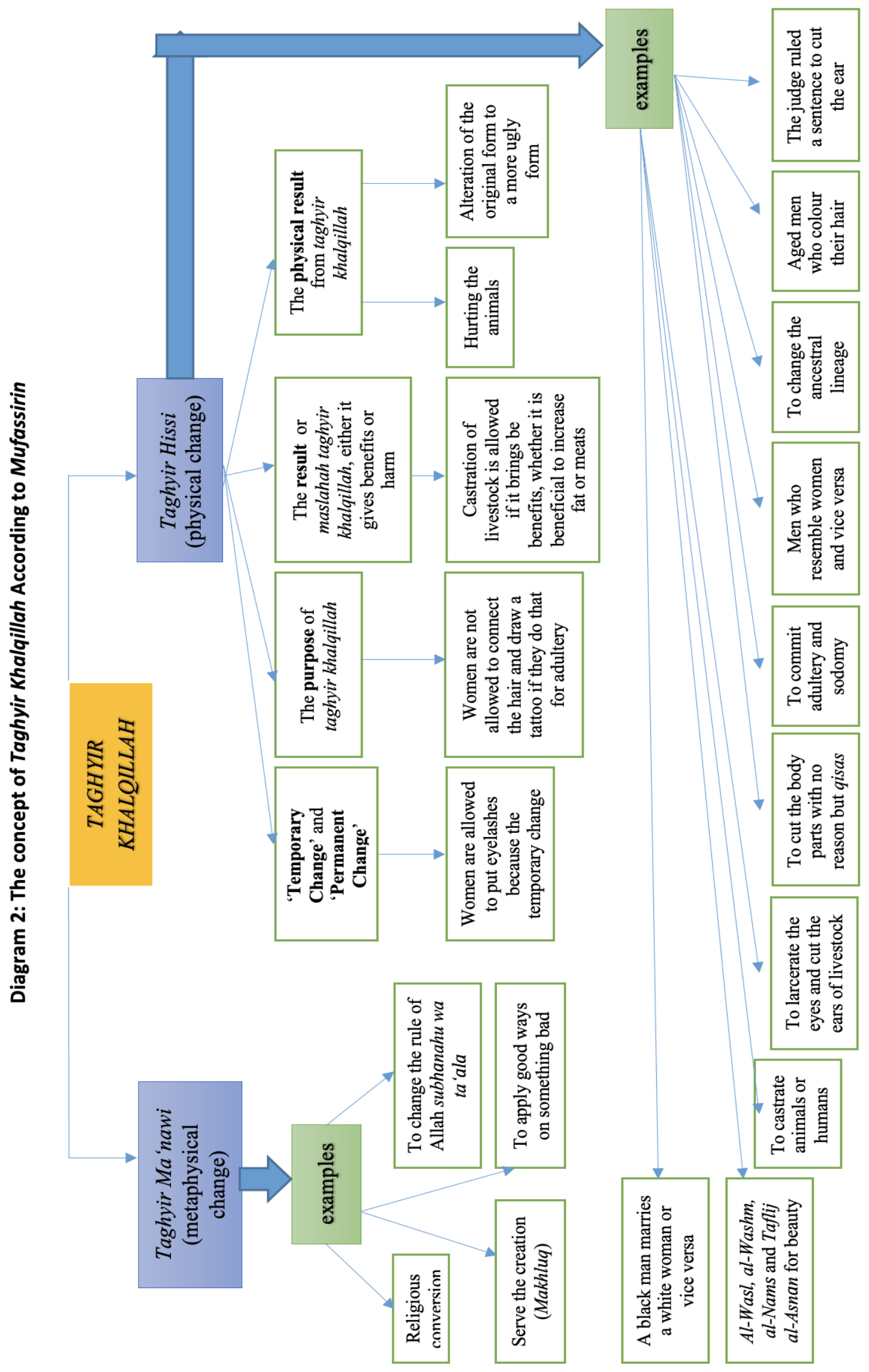




\section{Conclusion}

In the advancement era of science and technology of today, many novel developments, especially in medicine, have led to the transformation of Allah's creation. There are abundant of treatment procedures offered in the market to alter the phyiscal appearance of human beings to their desired form. Thus, the introduction of the concept of taghyir khalqillah according to mufassirin can be a starting point for related parties to assess their actions on which basis are they on as stated in diagram 2. However, further research on this concept requires advanced continuation of study and in particular, from the perspectives of muhaddithin and fuqaha'. The combination of these three perspectives will make the concept more refined and become reference for related parties.

\section{Acknowledgement}

This work is supported by Ministry of Higher Education Malaysia under the Fundamental Research Grant Scheme (FRGS/1/2020/SSIO/UTM/02/23). We are grateful to Mr. 'Abdul Muhaimin bin Misran for his contribution in translating this article.

\section{Reference}

The Noble Qur'an.

'Abd al-Baqi, M. F. (2001). Al-Mu'jam al-Mufahris li Alfaz al-Qur'an al-Karim. Dar al-Hadith.

'Abd al-Mun'im, M. A. R. (1999). Mu'jam al-Mustalahat wa al-Alfaz al-Fiqhiyyah. Dar alFadilah.

'Abduh, M. (1910). Tafsir al-Qur'an al-Hakim. Matba'ah al-Manar.

Abu Dawud, S. A. (n.d.). Sunan Abi Dawud. al-Maktabah al-'Asriyyah.

Al-Andalusi, A. H. G. (2001). Al-Muharrar al-Wajiz fi Tafsir al-Kitab al-'Aziz. Dar al-Kutub al'Ilmiyyah.

Al-Asbahi, M. A. (2004). Al-Muwatta Imam Malik. Mu'assasah Zayd bin Sultan.

Al-Asfahani, H. M. R. (1991). Al-Mufradat fi Gharib al-Qur'an. Dar al-Qalam.

Al-Baihaqi, A. H. (2003). Al-Sunan al-Kubra. Dar al-Kutub al-'Ilmiyyah.

Al-Bukhari, M. I. (2001). Sahih al-Bukhari. Dar Tawq al-Najah.

Al-Dhahabi, M. A. U. (1985). Siyar A'lam al-Nubala'. Mu'assasah al-Risalah.

Al-Dhahabi, M. H., and al-Dhahabi, M. M. (2005). Al-Tafsir wa al-Mufassirun. Dar al-Hadith.

Al-Duwaish, A. A. R. (2003). Fatawa al-Lajnah al-Da'imah. Riyadh. Dar al-Mu'ayyid li al-Nashr wa al-Tawzi'.

Al-Jassas, A. A. R. (1992). Ahkam al-Qur'an. Dar Ihya' al-Turath al-'Arabi.

Al-Naisaburi, M. H. (1954). Sahih Muslim. Dar Ihya' al-Kutub al-'Arabi.

Al-Nasa'i, A. S. A. K. (2001). Al-Sunan al-Kubra. Mu'assasah al-Risalah.

Al-Nawawi, Y. S. M. (1972). Al-Minhaj fi Sharh Sahih Muslim. Dar Ihya' al-Turath.

Al-Qurashi, I. U. K. (1999). Tafsir al-Qur'an al-'Azim. Dar Tibah.

Al-Qurtubi, M. A. A. B. (2006). Al-Jami' li Ahkam al-Qur'an. Mu'assasah al-Risalah.

Al-Qurtubi, M. Y. (1993). Tafsir al-Bahr al-Muhit. Dar al-Kutub al-'Ilmiyyah.

Al-Razi, M. F. D. U. (1981). Mafatih al-Ghayb. Beirut: Dar al-Fikr.

Al-Shawkani, M. A. (2007). Fath al-Qadir al-Jami' bayn Fannai al-Riwayah wa al-Dirayah min 'Ilm al-Tafsir. Dar al-Ma'rifah.

Al-Tabari, M. J. (n.d.). Jami' al-Bayan 'an Ta'wil Ayi al-Qur'an. Maktabah Ibn Taimiyyah.

Al-Tirmidhi, M. I. S. (1975). Sunan al-Tirmidhi. Matba'ah al-Babi al-Halabi.

Al-Zamakhshari, M. U. (1998). Al-Kashshaf 'an Haqa'iq Ghawamid al-Tanzil wa 'Uyun alAqawil fi Wujuh al-Ta'wil. Maktabah al-'Ubaikan. 
Hanbal, A. (2001). Musnad al-Imam Ahmad bin Hanbal. Beirut: Mu'assasah al-Risalah. Ibn al-'Arabi, M. A. M. (2007). Al-Masalik fi Sharh Muwatta' Malik. Dar al-Gharb al-Islami. Ibn Hibban, M. T. (1993). Sahih Ibn Hibban bi Tartib Ibn Balban. Mu'assasah al-Risalah. Jamaah min Kibar al-lughawiyyin al-'Arab (1989). Al-Mu'jam al-'Arabiyyah al-Asasi, (1 ${ }^{\text {st }}$ ed.). al-Munazzamah al-'Arabiyyah li al-Tarbiyyah wa al-Thaqafah wa al-'Ulum.

Rida, M. R. (1910). Tafsir al-Manar. Cairo: Matba'ah al-Manar. 